\title{
FERTILIZER MAINTENANCE NITROGEN IN VEGETATIVE DEVELOPMENT AND PRODUCTION OF PEACH
}

Letícia Vanni Ferreira ${ }^{1}$, Luciano Picolotto ${ }^{2}$, Michél Aldrighi Gonçalves ${ }^{3}$, Ricardo Alexandre Valgas ${ }^{4}$ \& Luis Eduardo Corrêa Antunes ${ }^{4}$

\footnotetext{
${ }^{1}$ Universidade Federal de Pelotas. E-mail: letivf@hotmail.com

${ }^{2}$ Universidade Federal de Santa Catarina. E-mail: picolotto@gmail.com

${ }^{3}$ Prefeitura de Canguçu, Rio Grande do Sul.E-mail: aldrighimichel@gmail.com

[4Embrapa Clima Temperado. E-mail: ricardo.valgas@embrapa.br; luis.antunes@embrapa.br
}

\section{ABSTRACT}

Nitrogen is the most important nutrient for the peach tree, especially in the growth and formation of plants. This work was conducted in the experimental area from Embrapa Temperate Climate, Pelotas, in the state of Rio Grande do Sul, Brazil, between the years 2012 and 2014. The local soil is classified as Yellow Red Argisol. The treatments consisted of three genotypes ('BRS Kampai', 'BRS Rubimel' and 'Cascata 805') and three nitrogen fertilizer maintenance doses (0, 100 and $\left.200 \mathrm{~kg} \mathrm{ha}^{-1} \mathrm{~N}\right)$, using as source the urea, compared in a split plot experimental design. The objective was to evaluate the effect of nitrogen fertilization maintenance on plant development, production and fruit quality of different genotypes of peach trees grown in high density planting. Maintenance nitrogen fertilization, at the doses tested in this study, does not influence the productive development of peach trees, but influences vegetative parameters, such as plant height and green pruning mass. Yet, the genotypes 'BRS Kampai', 'BRS Rubimel' and 'Cascata 805' affect in both the vegetative growth and the productive development of the peach tree.

Keywords: Genotype plant nutrition, post-harvest, Prunus sp

\section{ADUBAÇÃO NITROGENADA DE MANUTENÇÃO NO DESENVOLVIMENTO VEGETATIVO E PRODUTIVO DE GENÓTIPOS DE PESSEGUEIRO}

\section{RESUMO}

Os principais componentes de produção do pessegueiro são influenciados pelo nitrogênio. $\mathrm{O}$ trabalho foi conduzido na Embrapa Clima Temperado, Pelotas, RS, Brasil, entre os anos de 2012 a 2014. 
O solo local foi classificado como Argissolo Vermelho Amarelo. Os tratamentos foram compostos por três genótipos de pessegueiro ('BRS Kampai', 'BRS Rubimel' e 'Seleção Cascata 805') e três doses de adubação nitrogenada de manutenção $\left(0,100\right.$ e $200 \mathrm{~kg} \mathrm{ha}^{-1}$ de $\mathrm{N}$, dispostos em um delineamento experimental em parcelas subdivididas. Esse trabalho teve como objetivo avaliar o efeito da adubação nitrogenada de manutenção sobre o desenvolvimento vegetativo e produtivo de pessegueiros cultivados em alta densidade de plantio. A adubação nitrogenada, nas doses testadas, não influencia no desenvolvimento produtivo de pessegueiros, porém afeta parâmetros vegetativos, como na altura das plantas e na massa verde de poda. Os genótipos 'BRS Kampai', 'BRS Rubimel' e 'Cascata 805' influenciam tanto no crescimento vegetativo como no desenvolvimento produtivo do pessegueiro.

Palavras-chave: Genótipo, doses de nitrogênio, nutrição de plantas, pós-colheita, Prunus sp

\section{INTRODUCTION}

Peach tree is a plant belonging to the family Rosaceae, composing the genus Prunus (MAYER, 2008). It has a rapid growth, with production from the third year (WAGNER JÚNIOR et al., 2014). In Brazil, the crop is expanding both in cultivated area and in productivity, considering the great market potential (MATIAS et al, 2014). The national production of peaches is currently 217,706 tons and is concentrated mainly in the South and Southeast regions, with the state of Rio Grande do Sul being the largest producer, with 127, 93 thousand tons (IBGE, 2017).

The annual production of peaches in Rio Grande do Sul in 2012 was 132,736 tons in 13,500 ha, with an average yield of $9.81 \mathrm{tha}^{-1}$. This productivity is considered low when compared to states such as Santa Catarina, Minas Gerais and São Paulo, with yields of $16.0 \mathrm{t} \mathrm{ha}^{-1}, 21.5 \mathrm{t} \mathrm{ha}^{-1}$ and $22.4 \mathrm{t} \mathrm{ha}^{-1}$, respectively (IBGE, 2017). Therefore, the search for management practices that allow higher yields is fundamental. Among these practices, fertilization stands out, since it can provide greater productive increases.

The main components of production in a peach tree are the number of fruits per plant and the mass of these fruits at maturity, both variables strongly influenced by nitrogen (N) (DELLA BRUNA et al., 2014), as this nutrient affects the growth of branches in size and /or number (DOLINSKI et al., 2005).

It should be noted that productive capacity is also influenced by genetic factors. In the region of Pelotas, in the last years, the producers have adopted dual purpose cultivars, that is, destined to the processing and the in natura consumption, as is the case of the cultivars BRS Kampai, BRS Rubimel and 
also of selection Cascade 805. This procedure has provided them with alternatives for exploring two types of market (RASEIRA et al., 2014).

In this context, the objective of this work was to evaluate the effect of maintenance nitrogen fertilization on vegetative and productive development of peach genotypes cultivated at high planting density.

\section{MATERIAL AND METHODS}

The orchard used in the experiment was implanted in 2006 in an experimental area of 0.1 ha belonging to Embrapa Clima Temperado, located in the municipality of Pelotas, in the state of Rio Grande do Sul, Brazil (coordinates 31 40 '41.29 "S and 52 26' 22.05" W and altitude of $70 \mathrm{~m}$ ). The climate of the region, according to the classification of Köppen, is mesothermic humid. The local soil is classified as Red Yellow Argisol (EMBRAPA, 2006). The productive cycles evaluated were 2012 and 2013. The plants were grafted on the 'Capdeboscq' graft, in a planting spacing of $1.5 \mathrm{~m} \times 5.0 \mathrm{~m}$ and a 'double Y' conduction system, being used as canopy the Selecção Cascata genotypes 805, 'BRS Kampai' and 'BRS Rubimel'. The management of the orchard, the cultural treatments and phytosanitary treatments were carried out according to the Technical and Specific Norms of the Integrated Production of Peaches.

According to soil analysis, the organic matter content was $1.4 \%$ (low) and the phosphorus (P) and potassium (K) contents were 17.9 (high) and $155 \mathrm{mg} \mathrm{dm}-3$ (very high), respectively. The $\mathrm{P}$ was applied in the form of triple superphosphate in the amount of $90 \mathrm{~kg} \mathrm{ha}^{-1}$. The treatments included nitrogen fertilization rates $\left(0,100,200 \mathrm{~kg} \mathrm{ha}^{-1}\right)$ and the fertilizer used was urea $(45 \% \mathrm{~N})$, distributed manually under the crown projection, forming a crown $30 \mathrm{~cm}$ away from the trunk. The doses were split with the application of $50 \%$ of $\mathrm{N}$ at the beginning of flowering, $30 \%$ after fruit thinning and $20 \%$ after harvest (CQFSRS / SC, 2016).

The experimental design was a randomized block in subdivided plots in a $3 \times 3$ factorial with three genotypes: 'BRS Kampai', 'BRS Rubimel' and 'Selection Cascade 805' and three Nitrogen doses: 0, 100 and $200 \mathrm{~kg}$ ha- 1, the plots being composed of fertilization rates and subplots by genotypes.

The vegetative variables evaluated were the following: trunk diameter ( $\mathrm{mm}$ ) obtained by two measurements with a digital caliper at $20 \mathrm{~cm}$ from the soil; (G plant-1), obtained by weighing the total of material removed in the winter pruning; average length of branches $(\mathrm{cm})$, obtained by the average length of two productive branches per plant chosen from the middle part of the Each plant; (N, P, K, Ca, 
$\mathrm{Mg}, \mathrm{Fe}, \mathrm{Mn}, \mathrm{Zn}, \mathrm{Cu}$, and B), and complete leaves were collected at the 15th week after full bloom (CQFS RS / SC, 2016).

In the productive phase, the following evaluations were carried out: fruit thinning, a practice performed in the second week of September, following the methodology described by Petri \& Pereira (2004). The thinned fruits were weighed, the number of fruits estimated and the average mass per fruit was obtained by the ratio of the total mass of fruits removed by the number of fruits thinned per plant; Production $\left(\mathrm{g} \mathrm{plant}^{-1}\right)$, evaluated by harvesting and weighing the total of fruits produced by the three central plants of each plot; Average fruit mass $\left(\mathrm{g}_{\text {fruit }}{ }^{-1}\right)$ estimated by dividing the total fruit mass of each plant by the number of fruits harvested per plant; Average number of fruits (fruit plant ${ }^{-1}$ ) obtained by counting the total fruits harvested per plant.

Statistical analyzes were performed with the SISVAR program - Variance Analysis System for Balanced Data - version 5.1 (FERREIRA, 2011).

\section{RESULTS AND DISCUSSION}

In the two harvests evaluated, no differences were observed regarding the nitrogen fertilization applied for the variables mean number of fruits and mean mass of the fruits removed in the thinning (Table 1). Regarding the total mass of fruits removed in the cycle of 2013, the dose of $100 \mathrm{~kg} \mathrm{ha}^{-1}$ of N provided the highest value, differing from the dose of $200 \mathrm{~kg} \mathrm{ha}^{-1}$ of $\mathrm{N}$.

In relation to the genotype factor, differences were observed regarding the mean mass of the fruits removed in the thinning, and the 'BRS Rubimel' cultivar stood out in relation to the selection 'Cascade 805 ' with the highest average in the two years evaluated ( $8.52 \mathrm{~g}$ in 2012 and 9.30 $\mathrm{g}$ in 2013), but did not differ from 'BRS Kampai'. This behavior was repeated in mature fruits, where 'BRS Rubimel' fruits showed higher mass in relation to 'Cascade 805', and still not differing from 'BRS Kampai', demonstrating that this is a characteristic of the cultivar (Table 2).

The $\mathrm{N}$ doses studied did not influence the production or the number of fruits produced per plant (Table 2). The lack of response of nitrogen fertilization to reproductive development has been observed in temperate seedlings in non-densified orchards (BRUNETTO et al., 2007; DOLINSKI et al., 2007).

During the first four years of application of $\mathrm{N}$ doses in apple trees (Malus domestica Borkh), Nosal (1990) observed no difference in production, however, a difference of up to $28 \%$ in accumulated productivity of eight years was observed. Although this effect of the age of the plant in this work is not proven, the behavior is believed to be similar. However, it should be noted that the response depends 
greatly on the organic matter content of each soil, for example, in Serra Gaúcha soils, it is of little use to raise $\mathrm{N}$ rates because of the high organic matter in the soil.

Table 1: Total fruit mass (MTFR), mean fruit number (NMFR) and average mass of fruits removed in the rind (MMFR) in 'BRS Kampai', 'BRS Rubimel' and 'Cascade 805' peach trees submitted to different doses of Nitrogen, in the seasons 2012 and 2013. Embrapa Clima Temperado, Pelotas, RS, 2017

\begin{tabular}{|c|c|c|c|}
\hline \multicolumn{4}{|l|}{ Season 2012} \\
\hline Genotypes & $\begin{array}{l}\text { MTFR } \\
\left(\text { g plant }^{-1}\right)\end{array}$ & $\begin{array}{l}\text { NMFR } \\
\text { (fruit plant }^{-1} \text { ) }\end{array}$ & $\begin{array}{l}\text { MMFR } \\
\text { (g fruit }^{-1} \text { ) }\end{array}$ \\
\hline ‘BRS Kampai’ & $1505.74^{\mathrm{ns}}$ & $216.98^{\mathrm{ns}}$ & $6.95 \mathrm{ab}$ \\
\hline 'BRS Rubimel' & 1063.03 & 146.54 & $8.52 \mathrm{a}$ \\
\hline 'Cascata 805' & 1198.51 & 219.37 & $5.77 \mathrm{~b}$ \\
\hline \multicolumn{4}{|c|}{ Doses of $\mathrm{N}\left(\mathrm{Kg} \mathrm{ha}^{-1}\right)$} \\
\hline 0 & $981.11^{\mathrm{ns}}$ & $201.84^{\mathrm{ns}}$ & $6.31^{\mathrm{ns}}$ \\
\hline 100 & 1298.89 & 236.77 & 7.05 \\
\hline 200 & 909.11 & 144.28 & 7.88 \\
\hline C.V. $(\%)^{1}$ & 42.86 & 40.70 & 32.07 \\
\hline \multicolumn{4}{|l|}{ Season 2013} \\
\hline \multicolumn{4}{|l|}{ Genotypes } \\
\hline 'BRS Kampai' & $1603.78 \mathrm{a}$ & $216.98^{\mathrm{ns}}$ & $6.61 \mathrm{ab}$ \\
\hline 'BRS Rubimel' & $1096.74 \mathrm{~b}$ & 145.74 & $9.30 \mathrm{a}$ \\
\hline 'Cascata 805' & $1315.07 \mathrm{ab}$ & 236.03 & $5.49 \mathrm{~b}$ \\
\hline \multicolumn{4}{|c|}{ Dose of $\mathrm{N}\left(\mathrm{Kg} \mathrm{ha}^{-1}\right)$} \\
\hline 0 & $1340.66 \mathrm{ab}$ & $194.57^{\mathrm{ns}}$ & $5.53^{\mathrm{ns}}$ \\
\hline 100 & $1599.63 \mathrm{a}$ & 247.88 & 7.81 \\
\hline 200 & $1075.29 \mathrm{~b}$ & 156.31 & 8.4 \\
\hline C.V. $(\%)^{1}$ & 27.87 & 39.11 & 41.06 \\
\hline
\end{tabular}

In 2012 the production per plant was not affected by the factors under study (Table 2). But, in the season of 2013, the average yield of the fruits showed a significant difference between the evaluated genotypes, demonstrating genetic variability among the evaluated materials. The selection Cascade 805 stood out in relation to 'BRS Rubimel' and 'BRS Kampai', presenting $10.19 \mathrm{~kg} \mathrm{plant}^{-1}$ in 2013 (Table 2). For the lack of effect of $\mathrm{N}$ doses on production one of the hypotheses is the low amount applied in the last application period, thus compromising the floral differentiation. 
Table 2: Average yield per plant (PMP), average number of fruits per plant (MFN) and average mass of fruits harvested in 'BRS Kampai', 'BRS Rubimel' and 'Cascade 805' peach trees submitted to different doses of Nitrogen in the harvests of 2012 and 2013. Embrapa Clima Temperado, Pelotas, RS, 2017

\begin{tabular}{|c|c|c|c|}
\hline \multicolumn{4}{|c|}{ Season 2012} \\
\hline Genotypes & $\begin{array}{l}\text { PMP } \\
\left(\text { Kg planta }^{-1}\right)\end{array}$ & $\begin{array}{l}\text { NMF } \\
\text { (fruit planta }^{-1} \text { ) }\end{array}$ & $\begin{array}{l}\text { MMF } \\
\left.\text { (g fruit }^{-1}\right)\end{array}$ \\
\hline 'BRS Kampai' & $7.05^{\mathrm{ns}}$ & $33.39^{\mathrm{ns}}$ & $204.53 \mathrm{~b}$ \\
\hline 'BRS Rubimel' & 8.52 & 37.32 & $292.78 \mathrm{a}$ \\
\hline 'Cascata 805' & 10.66 & 33.37 & $254.43 \mathrm{a}$ \\
\hline \multicolumn{4}{|c|}{ Doses of $N\left(\mathrm{Kg} \mathrm{ha}^{-1}\right)$} \\
\hline 0 & $8.90^{\mathrm{ns}}$ & $35.87^{\mathrm{ns}}$ & $197.29^{\mathrm{ns}}$ \\
\hline 100 & 9.20 & 37.16 & 187.64 \\
\hline 200 & 8.10 & 32.04 & 197.23 \\
\hline C.V. $(\%)^{1}$ & 37.66 & 34.67 & 13.22 \\
\hline \multicolumn{4}{|c|}{ Season 2013} \\
\hline Genotypes & $\begin{array}{l}\text { PMP } \\
\left(\text { g plant }^{-1}\right)\end{array}$ & $\begin{array}{l}\text { NMF } \\
\left(\text { fruit plant }^{-1}\right)\end{array}$ & $\begin{array}{l}\text { MMF } \\
\left(\text { g fruit }^{-1}\right)\end{array}$ \\
\hline 'BRS Kampai' & $1.73 \mathrm{~b}$ & $13.72 \mathrm{c}$ & $132.60^{\mathrm{ns}}$ \\
\hline 'BRS Rubimel' & $3.71 \mathrm{~b}$ & $26.41 \mathrm{~b}$ & 134.52 \\
\hline 'Cascata 805' & $10.19 \mathrm{a}$ & $53.49 \mathrm{a}$ & 112.00 \\
\hline \multicolumn{4}{|c|}{ Doses of $\mathrm{N}\left(\mathrm{Kg} \mathrm{ha}^{-1}\right)$} \\
\hline 0 & $5.26^{\mathrm{ns}}$ & $30.72^{\mathrm{ns}}$ & $121.08^{\mathrm{ns}}$ \\
\hline 100 & 4.35 & 25.94 & 136.72 \\
\hline 200 & 6.03 & 36.96 & 121.31 \\
\hline C.V. $(\%)^{1}$ & & 31.44 & 14.95 \\
\hline
\end{tabular}

There was a drastic reduction in the production of the 2012 harvest for the 2013 harvest. Probably the production per plant in the harvest of 2013 was inferior, compared to the previous harvest due to the lower number of cold hours accumulated during the year.

The number of fruits produced per plant in both evaluated crops was not affected by nitrogen fertilization (Table 2), reinforcing the hypothesis that the $\mathrm{N}$ application season may be detrimental to floral differentiation. These results disagree with those found by Dolinski et al. (2005), who report that the reduction in nitrogen fertilization negatively affects the number of fruits. Possibly the plants were devoid of nutritional depth and therefore there was no difference between the doses of $\mathrm{N}$ applied (table 4). 
In the 2013 crop, the number of fruits was influenced by the genotype, and the selection plants 'Cascata 805' provided the highest number of fruits per plant (53.49), differing from 'BRS Rubimel' $(26,41)$ and 'BRS Kampai' with the lowest number of fruits produced (13.72). However, in the previous harvest this result was different: there was no effect of the genotype on the number of fruits per plant. This result can be explained by the very variable climatic conditions from one year to the other, interfering in the accumulation of reserves and, therefore, in the floral differentiation of the different peach genotypes. In addition, in the year 2013 there were frosts, the 'BRS Kampai' genotype being the most precocious among the tested in this study and, therefore, the most impaired, because this phenomenon occurred during the flowering period of this cultivar.

In relation to the average fruit mass, no statistical differences were observed between the levels of the $\mathrm{N}$ dose factor, disagreeing with Della Bruna et al. (2014), who obtained for the 'Chimarrita' cultivar lower fruit mass in fruits from control plants. Possibly the doses of $\mathrm{N}$ had no effect on the production because it was still insufficient. This is possible because in both studied years the level of $\mathrm{N}$ in the leaf was below normal.

In the 2012 harvest, the 'BRS Rubimel' and the 'Cascade 805' selection presented higher average fruit masses compared to 'BRS Kampai', but this behavior was not repeated in the following year, probably due to the production oscillations that were also observed (Table 2). It should be noted that fruit size, besides being an inherent characteristic of each cultivar, depends on the fruit load of the plants, but, there is not always a direct relationship between increase of productivity and decrease of fruit size and vice versa (ALMEIDA et al., 2014). The 'BRS Kampai' genotype flowers a little before 'BRS Rubimel' and Cascade 805, so at the time of thinning the fruits of 'BRS Kampai' were larger than those of the other evaluated genotypes, with this the number of cells and consequently the mass of the fruits is different.

For the variable stem diameter, no significant differences were observed between the levels of factors studied in the two evaluation years (Table 3). This result is contrary to those described by Della Bruna et al. (2014), which affirm that there is a positive correlation between this variable and nitrogen fertilization. Two hypotheses are suggested, the first is that the applied amount of $\mathrm{N}$ has not yet been sufficient and the second is that the time to generate an effect on the plant has been insufficient. Thus, as the diameter of the trunk, the length of branches was not influenced by $\mathrm{N}$ levels and had on average a length of $34.15 \mathrm{~cm}$ (Table 3$)$. 
Table 3: Trunk diameter (DT), length of branches (CR) and number of vegetative buds per cm of branch, in 2013 and trunk diameter, plant height (AP), and green pruning mass (MVP) in 2014 in (BRS Kampai, BRS Rubimel, and Cascade 805) submitted to different nitrogen doses in the year 2013. Embrapa Clima Temperado, Pelotas, RS, Brazil, 2017

\begin{tabular}{|c|c|c|c|}
\hline \multicolumn{4}{|l|}{2013} \\
\hline Genotypes & DT (mm) & CR $(\mathbf{c m})$ & Buds $\mathrm{cm}^{-1}$ of branches \\
\hline 'BRS Kampai’ & $106.08^{\mathrm{ns}}$ & $31.94^{\mathrm{ns}}$ & $2.02 \mathrm{ab}$ \\
\hline 'BRS Rubimel' & 101.30 & 35.80 & $2.24 \mathrm{a}$ \\
\hline 'Cascata 805' & 127.95 & 34.73 & $1.74 \mathrm{~b}$ \\
\hline \multicolumn{4}{|c|}{ Dose of $N\left(\mathrm{Kg} \mathrm{ha}^{-1}\right)$} \\
\hline 0 & $101.2^{\mathrm{ns}}$ & $35.21^{\mathrm{ns}}$ & $2.01^{\mathrm{ns}}$ \\
\hline 100 & 130.67 & 33.77 & 2.00 \\
\hline 200 & 103.45 & 33.48 & 1.99 \\
\hline C.V. $(\%)^{1}$ & 33.45 & 13.48 & 19.37 \\
\hline \multicolumn{4}{|l|}{2014} \\
\hline Genotypes & DT (mm) & $\mathbf{A P}(\mathbf{c m})$ & \\
\hline 'BRS Kampai' & $108.99^{\mathrm{ns}}$ & $264.83^{\mathrm{ns}}$ & \\
\hline 'BRS Rubimel & 104.03 & 271.09 & \\
\hline 'Cascata 805' & 108.05 & 248.64 & \\
\hline \multicolumn{4}{|c|}{ Dose of $\mathrm{N}\left(\mathrm{Kg} \mathrm{ha}^{-1}\right)$} \\
\hline 0 & $102.55^{\mathrm{ns}}$ & $220.77 \mathrm{~b}$ & \\
\hline 100 & 108.86 & $275.13 \mathrm{a}$ & \\
\hline 200 & 109.66 & $288.67 \mathrm{a}$ & \\
\hline C.V. $(\%)^{1}$ & 8.91 & 8.38 & \\
\hline \multicolumn{4}{|c|}{ MVP $\left(\right.$ g plant $\left.^{-1}\right)$} \\
\hline & \multicolumn{3}{|c|}{ Doses of $\mathrm{N}\left(\mathrm{kg} \mathrm{ha}^{-1}\right)$} \\
\hline Genotypes & $\mathbf{0}$ & 100 & 200 \\
\hline ‘BRS Kampai’ & $1683.33 \mathrm{~B} \mathrm{a}$ & $3500.00 \mathrm{~A} \mathrm{a}$ & $6675.00 \mathrm{~A} \mathrm{a}$ \\
\hline 'BRS Rubimel' & $1380.00 \mathrm{C} \mathrm{a}$ & $7050.00 \mathrm{~A} \mathrm{~b}$ & $6713.33 \mathrm{~B}$ a \\
\hline 'Cascata 805' & $1250.00 \mathrm{~B} \mathrm{a}$ & $1610.00 \mathrm{~B} \mathrm{c}$ & $5345.00 \mathrm{~A} \mathrm{a}$ \\
\hline
\end{tabular}

C.V. $(\%)^{\mathbf{1}}$

18.32

${ }^{1}$ Coefficient of variation.

* Averages followed by different lowercase letters in the same column and averages followed by different uppercase letters in the same row differ from each other by the $5 \%$ probability of error level test. * Ns (not significant).

In the present study, comparing the $\mathrm{N}$ doses, it is observed in the three genotypes that the fresh mass of pruned material is directly proportional to the dose of $\mathrm{N}$. There was an interaction between the factors studied, and the plants that received the highest dose were which presented the highest green pruning mass (Table 3). $\mathrm{N}$ is directly related to the growth of plants, as widely reported in the literature. Della Bruna et al. (2014) showed that N promoted an increase of the mass of branches, increasing the intensity of the green pruning, that is to say, the different doses of $\mathrm{N}$ significantly influenced the pruned fresh mass. The average height of the plants was influenced by nitrogen fertilization, and the plants that 
received 100 and $200 \mathrm{~kg}$ ha-1 had the highest average heights (275.13 and $288.67 \mathrm{~cm}$, respectively) in relation to the control treatment $(220,77 \mathrm{~cm})$ (Table 3). These data are in agreement with the results obtained by Della Bruna et al. (2014), where they verified increase in height of the plants with the supply of N. According to Nunes et al. (2008), the highest percentages of $\mathrm{N}$ in plant tissues contribute to higher growth in height, diameter, leaf area, fresh biomass, and dry shoot.

The number of vegetative buds per $\mathrm{cm}$ of branch was influenced only by the genotype factor. The highest number of buds per cm of the genotypes 'BRS Rubimel' $(2,24)$ and 'BRS Kampai' $(2,02)$ differed from 'Cascade 805' $(1,74)$ (Table 3). However, this variable was not influenced by the dose of nitrogen fertilization, thus indicating a genetic characteristic of the studied materials. Similar results were verified by Della Bruna et al. (2014) who, when testing different doses of urea and calcium nitrate in peach fertilization of the 'Aurora' and 'Chimarrita' cultivars in the south of Santa Catarina also did not verify significance for this characteristic.

In the present work, it was observed that in the three genotypes the fresh mass of pruned material is directly proportional to the dose of N. There was an interaction between the studied factors, and the plants that received the highest dose were those with the highest mass pruning green (Table 3). Della Bruna et al. (2014) showed that $\mathrm{N}$ promoted an increase of the mass of branches, that is, the different doses of $\mathrm{N}$ significantly influenced the pruned fresh mass.

The genotypes had a similar behavior, and only in the dose of $100 \mathrm{~kg} \mathrm{ha}^{-1}$ there was a significant difference in relation to the material removed in pruning. 'BRS Rubimel' presented more pruning mass (7050 g), 'BRS Kampai' the intermediate value (3500 g) and 'Cascade 805' the lowest pruning mass (1610 g). $\mathrm{N}$ is directly related to plant growth, as reported in the literature.

The macronutrient leaf content observed in this study followed a decreasing order: $\mathrm{N}>\mathrm{K}>\mathrm{Ca}>$ Mg> P (Table 4). These data are in agreement with Thomaz et al. (2014), who observed this same ordering.

The treatments with nitrogen fertilization also showed higher total $\mathrm{N}$ contents in the leaves in the two harvests evaluated (Table 4). Thus, the plants receiving the highest $\mathrm{N}$ dose were also the ones with the highest leaf $\mathrm{N}$ content in 2012. In the following year, the plants that received $\mathrm{N}$, regardless of the dose (100 or $200 \mathrm{~kg} \mathrm{ha}^{-1}$ of $\mathrm{N}$ ) differed from the zero dose, presenting the highest levels of leaf N. And agreeing with the results obtained by Dolinski et al. (2005), and Brunetto et al. (2007). However, the levels were below normal, as established by the RS / SC (2016) Soil Chemistry and Fertility Commission, reinforcing the hypothesis that there may have been an underdosing of $\mathrm{N}$. 
Table 4: Nutrient contents in peach leaves 'BRS Kampai', 'BRS Rubimel' and 'Cascade 805' submitted to different doses of N, in the years of 2012 and 2013. Embrapa Clima Temperado, Pelotas, RS, 2017

\begin{tabular}{|c|c|c|c|c|c|c|}
\hline \multirow{2}{*}{$\begin{array}{l}2012 \\
\text { Genotypes } \\
\end{array}$} & \multicolumn{6}{|c|}{ Macronutrient content (\%) } \\
\hline & $\mathbf{N}$ & $\mathbf{P}$ & K & $\mathbf{C a}$ & $\mathbf{M g}$ & \\
\hline 'BRS Kampai' & $3.22 \mathrm{a}$ & $0.27 \mathrm{a}$ & $1.90^{\mathrm{ns}}$ & $1.67 \mathrm{~b}$ & 0.5 & \\
\hline 'BRS Rubimel' & $2.94 \mathrm{ab}$ & $0.22 \mathrm{~b}$ & 2.12 & $2.06 \mathrm{a}$ & 0.4 & \\
\hline 'Cascata 805' & $2.85 \mathrm{~b}$ & $0.27 \mathrm{a}$ & 1.91 & $1.87 \mathrm{ab}$ & 0.6 & \\
\hline \multicolumn{7}{|c|}{ Doses of $N\left(\mathrm{Kg} \mathrm{ha}^{-1}\right)$} \\
\hline 0 & $2.80 \mathrm{~b}$ & $0.28 \mathrm{a}$ & $1.94^{\mathrm{ns}}$ & $1.84^{\mathrm{ns}}$ & 0.6 & \\
\hline 100 & $3.17 \mathrm{a}$ & $0.24 \mathrm{~b}$ & 1.90 & 1.88 & 0.5 & \\
\hline 200 & $3.05 \mathrm{a}$ & $0.25 \mathrm{~b}$ & 2.08 & 1.87 & 0.5 & \\
\hline C.V. $(\%)$ & 8.02 & 10.45 & 17.39 & 13.53 & 19. & \\
\hline \multicolumn{7}{|l|}{2013} \\
\hline \multicolumn{7}{|l|}{ Genotypes } \\
\hline 'BRSKampai' & $2.73^{\mathrm{ns}}$ & $0.34^{\text {ns }}$ & $2.06^{\mathrm{ns}}$ & $1.14^{\mathrm{ns}}$ & \multicolumn{2}{|c|}{$0.44 \mathrm{~b}$} \\
\hline 'BRSRubimel' & 2.78 & 0.34 & 2.15 & 1.28 & \multicolumn{2}{|c|}{$0.49 \mathrm{ab}$} \\
\hline Cascata 805 & 2.99 & 0.32 & 2.16 & 1.27 & \multicolumn{2}{|c|}{$0.50 \mathrm{a}$} \\
\hline \multicolumn{7}{|c|}{ Doses of $N\left(\mathrm{Kg} \mathrm{ha}^{-1}\right)$} \\
\hline 0 & $2.47 \mathrm{~b}$ & $0.32^{\mathrm{ns}}$ & $2.01^{\mathrm{ns}}$ & $1.09 \mathrm{~b}$ & \multicolumn{2}{|c|}{$0.46^{\mathrm{ns}}$} \\
\hline 100 & $2.83 \mathrm{ab}$ & 0.33 & 2.12 & $1.33 \mathrm{~b}$ & \multicolumn{2}{|c|}{0.51} \\
\hline 200 & $3.20 \mathrm{a}$ & 0.35 & 2.24 & $1.33 \mathrm{a}$ & \multicolumn{2}{|c|}{0.47} \\
\hline C.V. $(\%)^{1}$ & 9.46 & 12.25 & 9.68 & 16.35 & \multicolumn{2}{|c|}{8.34} \\
\hline 2012 & \multicolumn{6}{|c|}{ Micronutrients rate $\left(\mathrm{mg} \mathrm{kg}^{-1}\right)$} \\
\hline Genotypes & Fe & Mn & & Zn & $\mathrm{Cu}$ & $\mathbf{B}^{*}$ \\
\hline Kampai & $102.78^{\mathrm{ns}}$ & $117.89^{\mathrm{ns}}$ & & $11.44 \mathrm{a}$ & $5.77 \mathrm{ab}$ & $39.44^{\mathrm{ns}}$ \\
\hline Rubimel & 94.44 & 113.44 & & $9.22 \mathrm{~b}$ & $5.00 \mathrm{~b}$ & 38.11 \\
\hline Cascata 805 & 130.22 & 136.66 & & $11.00 \mathrm{ab}$ & $5.89 \mathrm{a}$ & 38.22 \\
\hline \multicolumn{7}{|c|}{ Dose of $N\left(\mathrm{Kg} \mathrm{ha}^{-1}\right)$} \\
\hline 0 & $125.22^{\mathrm{ns}}$ & $121.78^{\mathrm{ns}}$ & & $9.66^{\mathrm{ns}}$ & $5.22^{\mathrm{ns}}$ & $40.44 \mathrm{a}$ \\
\hline 100 & 98.00 & 129.11 & & 11.33 & 5.77 & $37.66 \mathrm{~b}$ \\
\hline 200 & 104.22 & 117.11 & & 10.66 & 5.66 & $37.66 \mathrm{~b}$ \\
\hline C.V. $(\%)^{1}$ & 47.64 & 37.38 & & 15.58 & 12.49 & 6.48 \\
\hline \multicolumn{7}{|l|}{2013} \\
\hline Genotypes & $\mathbf{F e}$ & Mn & & $\mathbf{Z n}$ & $\mathbf{C u}$ & $\mathbf{B} * *$ \\
\hline Kampai & $60.66^{\mathrm{ns}}$ & $83.33^{\mathrm{ns}}$ & & $12.66^{\mathrm{ns}}$ & $7.00^{\mathrm{ns}}$ & - \\
\hline Rubimel & 63.55 & 90.22 & & 14.11 & 7.70 & - \\
\hline Cascata 805 & 60.66 & 100.66 & & 13.33 & 7.11 & - \\
\hline \multicolumn{7}{|c|}{ Doses of $\mathrm{N}\left(\mathrm{Kg} \mathrm{ha}^{-1}\right)$} \\
\hline 0 & $56.77^{\mathrm{ns}}$ & $89.44^{\mathrm{ns}}$ & & $12.54^{\mathrm{ns}}$ & $6.66^{\mathrm{ns}}$ & - \\
\hline 100 & 63.66 & 97.44 & & 13.37 & 7.44 & - \\
\hline 200 & 69.00 & 85.33 & & 4.20 & 7.77 & - \\
\hline C.V. $(\%)^{1}$ & 16.45 & 40.80 & & 13.27 & 17.72 & - \\
\hline
\end{tabular}

${ }^{1}$ Coefficient of variation.

Means followed by distinct letters in the column differ from each other by the Tukey test at $5 \%$ of error probability. * Ns (not significant) ** was not evaluated in 2013 
The K levels were not affected, unlike the observed by Sete et al. (2015), which verified a quadratic increase of $\mathrm{K}$ with the increase of the dose of organic compound produced from waste from juice industries, poultry slaughtering and sawdust. This increase of $\mathrm{K}$ may have occurred due to the fact that the nutrient is found in part in the free form in the residue, different from the present work in which the $\mathrm{K}$ was not supplied to the plants. The levels of $\mathrm{P}$ did not differ statistically. These data disagree with those obtained by Mattos et al. (1991), who also found an inverse relationship between the applied N dose and the foliar $\mathrm{P}$ content. However, in the following year, the $\mathrm{N}$ applied dose did not influence the $\mathrm{P}$ content of the peach leaves, in agreement with the one verified by Dolinski et al. (2005). Mattos et al. (1991), explains that the relationships between the leaf contents of these elements can vary according to the climatic conditions.

According to the manual of fertilization and liming, the normal Mg content varies from 0.52 $0.83 \%$, showing that the cultivar 'BRS Rubimel' was below normal in both evaluated years, an aspect also observed in the 'BRS Kampai' in the second year of evaluation, thus indicating the possibility of other related effects (Table 4).

Micronutrients Fe and Mn were not affected by the factors under study in any of the study years. $\mathrm{Zn}$ and $\mathrm{Cu}$ were not influenced by nitrogen fertilization, in agreement with the data obtained by Dolinski et al. (2005), which in three years of evaluation in Lapa, PR, also did not observe differences. However, in the first year evaluated, it was observed that the genotype factor had influence under these elements, highlighting 'Cascade 805' and 'BRS Kampai' with the highest levels of $\mathrm{Cu}$ and $\mathrm{Zn}$ in 2012.

In the present study, no statistical differences were observed in relation to the genotype, with leaf boron (B) being influenced only by nitrogen fertilization. The treatment that did not receive $\mathrm{N}$ showed the highest concentration of leaf B (40.44 mg kg-1), compared to the plants that received 100 and $200 \mathrm{~kg}$ $\mathrm{ha}^{-1}$ of $\mathrm{N}$, which presented the same mean value $\left(37.66 \mathrm{mg} \mathrm{kg}^{-1}\right.$ ) of leaf B. According to Shelp et al. (1995) there is antagonism between B and nitrogenous forms.

\section{CONCLUSIONS}

The maintenance nitrogen fertilization at the doses tested in this study $\left(0,100\right.$ and $200 \mathrm{~kg} \mathrm{ha}^{-1}$ of $\mathrm{N}$ ) has no effect on the productive development of peach trees, but it influences vegetative parameters such as green pruning mass and plant height. The dose of $100 \mathrm{~kg} \mathrm{ha}^{-1}$ provides vigor equivalent to a dose of $200 \mathrm{~kg} \mathrm{ha}^{-1}$, and is therefore recommended since the producer can achieve the same effect by using less fertilizer. 
Yet, the genotype affects both the vegetative growth and the productive development of peach trees grown in high planting density. The 'Cascade 805 ' genotype is more productive than 'BRS Kampai' and 'BRS Rubimel'.

\section{ACKNOWLEDGMENTS}

To the Coordination of Improvement of Higher Education Personnel (CAPES) and the Brazilian Agricultural Research Corporation (EMBRAPA) for financial support.

\section{REFERENCES}

ALMEIDA, G.; MAGRIN, F.P.; SOLDATELLI, P.; FIORAVANÇO, J.C.2014. Fenologia e produtividade de cultivares de pessegueiro. Revista de Ciências Agroveterinárias, Lages, SC, v.13, n.3, p.255-265.

BRUNETTO, G.; CERETTA, C.A.; KAMINSKI, G.; DE MELLO, G.W.B.; LOURENZI, C.R.; FURLANETTO, V.; MORAES, A. 2007. Aplicação de nitrogênio em videiras na Campanha Gaúcha: Produtividade e características químicas do mosto da uva. Ciência Rural, Santa Maria, RS, v.37, n.2, p.389-393.

Comissão de química e fertilidade do solo - RS/SC. 2016. Manual de adubação e calagem para os Estados do Rio Grande do Sul e de Santa Catarina. $11^{\text {a }}$ Ed. SBCS Núcleo Regional Sul, Santa Maria, RS, $375 \mathrm{p}$.

DELLA BRUNA, E.; BACK, A.J. 2014. Adubação Nitrogenada em Pessegueiros 'Aurora' e 'Chimarrita'. Revista Tecnologia e Ambiente, Criciúma, SC, v. 20, n.1, p.1413-8131.

DOLINSKI, M.A. SERRAT, B.M.; MOTTA, A.C.V.; CUQUEL, F.L.; SOUZA, S.R.; MAY-DE MIO, L.L.; MONTEIRO, L.B.2005. Produção, teor foliar e qualidade de frutos do pessegueiro "Chimarrita" em função da adubação nitrogenada, na região da Lapa - PR. Revista Brasileira de Fruticultura, Jaboticabal, SP, v. 27, n.2, p.295-299.

DOLINSKI, M.A.; MOTTA, A.C.V.; SERRAT, B.M.; MAY-DE-MIO, L.L.; MONTEIRO, L.B.2007. Adubação nitrogenada e potássica na produtividade da ameixeira 'Reubennel', na região de Araucária - PR. Revista Brasileira de Fruticultura, Jaboticabal, SP, v. 29, n. 2, p. 364-370.

Embrapa. Empresa Brasileira de Pesquisa Agropecuária (CNPS). 2006. Sistema brasileiro de classificação de solos. CNPS. Rio de Janeiro. 412p.

FERREIRA, D.F. 2011. Sisvar: a computerstatisticalanalysis system. Ciência e Agrotecnologia (UFLA), Lavras, MG, v. 35, n.6, p. 1039-1042.

IBGE - Instituto Brasileiro de Geografia e Estatística, 2017. Produção agrícola municipal. Rio de Janeiro, RJ. Available at: 〈http://www.sidra.ibge.gov.br/bda/ Tabela/listabl.asp? $\mathrm{z}=\mathrm{teo}=11 \mathrm{ei}=\mathrm{Pec}=1613$ > Access in: February 10 $0^{\text {th }}, 2016$.

LORETI, F.; MASSAI, R. 2006. State of the art on peach rootstocks and orchard systems. Acta Horticulturae, Belgium, v.37, n.713, p.253-268.

MATIAS, R.G.; RIBEIRO, M.R.; SILVA, D.F.P.; COSTA E SILVA, J.O.; OLIVEIRA, S.P.; BRUCKNER, C. 2014. Características físicas e químicas de pêssego em função da altura de inserção na planta. Comunicata Scientiae, Bom Jesus, PI, v. 5, n.4, p. 435-440. 
MATTOS, M.L.T.; FREIRE, C.J.S.; MAGNANI, M. 1991. Crescimento e teores foliares de N, P, K, Ca e $\mathrm{Mg}$ em pessegueiro cv. Diamante com diferentes níveis de $\mathrm{N}$ aplicado ao solo. Pesquisa Agropecuária Brasileira, Brasília, DF, v. 26, n.9, p.1315-1321.

MAYER, N.A.; LEMOS, E.G.M.; PEREIRA, F.M.; WICKERT, E. 2008. Caracterização de três genótipos de umezeiro (Prunus mume Sieb. Et Zucc.) por marcadores RAPD. Revista Brasileira de Fruticultura, Jaboticabal, SP, v.30, n.4, p.1045-1050.

NOSAL, K.; PONIEDZIALEK, W.; KROPP, K.; POREBSKI, S. 1990. Effectiveness of nitrogen and potassium fertilization of apple trees. Acta Horticulturae, Hague, v. 274, p. 361-364.

NUNES, J.L.S.; SOUZA, P.V.D.; MARODIN, G.A.B.; FACHINELLO, J.C. 2008. Incremento no desenvolvimento do porta-enxerto de pessegueiro 'Aldrighi' por fungos micorrizicos arbusculares autóctones. Ciência agrotecnologia, Lavras, v. 32, n. 6, p. 1787-1793.

PETRI, J.L.; PEREIRA, J.F.M. RALEIO DE FRUTOS. IN: MONTEIRO, L.B.; MIO, L.L.M.D.; SERRAT, B.M.; MOTTA, A.C.; CUQUEL, F.L.2004. Fruteiras de caroço: Uma visão ecológica. UFPR. Curitiba, PR, p. 129-134.

RASEIRA, M.C.B.; NAKASU, B.H.; UENO, B.; SCARANARI, C. 2010.Pessegueiro: Cultivar BRS Kampai. Revista Brasileira de Fruticultura, Jaboticabal, SP, v.32, n.4, p. 1275-1278.

RASEIRA, M.D.C.B; PEREIRA, J.F.M.; CARVALHO, F.L.C. 2014. Pessegueiro.Embrapa Informação Tecnológica, Brasília, DF, v.1, n.1, p. 259-281.

RUFAT, J.; DOMINGO, X.; ARBONÉS.A.; PASCUAL, M.; VILLAR, J.M. 2011.Interaction between water and nitrogen management in peaches for processing. Irrigation Science, Germany, v. 29, n.4, p. 321-329.

SETE, P.B.; MELO, G.W.B.; OLIVEIRA, B.S. FREITAS, R.F.; MAGRO, R.; AMBROSINI, V.G.; TRAPP, T.; COMIN, J.J.; GATIBONI, L.C.; BRUNETTO, G. 2015.Perdas de nitrogênio do solo e resposta do pessegueiro à adição de composto orgânico. Ciência Rural, Santa Maria, RS, v.45, n.4, p. 657-657.

SHELP, B.J.; MARENTES, E.; KITHEKA, A.M.; 1995. Vivekanandan, P. Boron mobility in plants. PhysiologiaPlantarum, Kobenhavn. n.2, v.94, p. 356-361.

THOMAZ, Z. F. P.; SCHUCH, M.W.; PEIL, R.M.N; TIM, C.R.F. 2014. "Development of peach rootstocks minicuting obtained in two times in system growing without soil." Revista Brasileira de Fruticultura v.36. n.4 p. 988-995.

WAGNER JÚNIOR, A; BRUCKNER, C.H; CITADIN, I. 2014. Cultivo do Pessegueiro. In: Pio, R. Cultivo de Fruteiras de Clima Temperado em Regiões Subtropicais e Tropicais. Lavras, MG: Ed. UFLA. 